\title{
CONDitionals IN NDENDEULE ${ }^{1}$
}

\author{
Deo Ngonyani \\ Michigan State University
}

\begin{abstract}
Ndendeule, a Bantu language spoken in southern Tanzania, has six conditional constructions identified by conditional markers. Construction I is marked by the subordinating conjunction anda 'if,' while Construction II is characterized by the conditional prefix nga- which appears on both the protasis and apodosis. The dependent $a k a$ - in the if-clause marks Construction III. Construction IV is a negative conditional where the negative is marked in the subordinated clause. Construction V is identified as a directive conditional in which the protasis is either imperative or subjunctive and the main clause is subjunctive. Construction VI is a concessive conditional characterized by biclausal subjunctive protasis. It is argued that reality or unreality is expressed by the choice of the conditional marker on the protasis. Conditional markers express the speaker's assumption about whether the protasis is factual or counterfactual. Constructions marked by anda 'if' and the dependent prefix -aka-, and the negative conditional express factual and probable conditions, while the use of nga- expresses counterfactual conditions. Tense, aspect and mood markers do not contribute to the conditional interpretation. They relate the time and completion of the event. Semantically, Ndendeule conditionals appear on Taylor's (1997) gradient on three points, namely, factual, hypothetical and counterfactual.
\end{abstract}

Keywords: conditional, Ndendeule, Bantu

\section{Introduction}

Ndendeule (iso code dne) is a Bantu language spoken in southern Tanzania by an estimated 135,753 people (Mradi wa Lugha za Tanzania, 2009). In Maho's (2003) revised referential classification of Bantu languages by Guthrie (1967-71), Ndendeule is coded as N101 in the Manda group. Nurse groups it with the Rufiji languages (Nurse 1988), with Ngindo (P14) and Matengo (N13) as its closest relatives. Ndendeule has not been much described, except for Ngonyani (2010), which exists only as a manuscript. Data for this paper are supplied by the author, a native speaker from the Namtumbo District in Tanzania.

A conditional construction is a complex sentence that consists of a subordinate clause known as a protasis, or if-clause, and a main clause known as an apodosis. In logic, the protasis is designated as $p$ and the apodosis as $q$. The protasis expresses a contingency upon which the fulfillment of the proposition of the apodosis depends (Thompson, Longacre and Hwang, 2007; Quirk et al. 1985; Podlesskaya, 2001). A prototypical example of a conditional comes from Quirk et al. (1985:1088):

1 Many thanks to two anonymous reviewers, Tucker Childs and Steve Nicolle for the valuable comments, queries and suggestions that enabled me to improve this paper. I take full responsibility for the shortcomings of the paper. 
(1) If the weather is fine, (then) we'll have a barbecue.

$p$

$q$

The fulfillment of $q$ is dependent on the truth of $p$. This means we will have a barbecue on the condition that the weather is fine. Adapting Comrie's (1986) proposed parameters of description of conditionals, this paper focuses on: (a) markers of protasis and apodosis in Ndendeule, (b) clause order, (c) interpretation, and (d) how form and function are interrelated.

Following this introductory section, an overview of the morphology of the Ndendeule verb is provided in $\$ 2$ to serve as background for how conditional markers and inflections interact. Markers of protases and apodoses are described in $\S 3$. In $\S 4$, the order of the two clauses is presented. The interpretation of conditionals is discussed in $§ 5$. In addition, tense, aspect and mood inflections of conditional constructions are explored in this section. Concluding remarks appear in $\S 6$.

\section{Background to Ndendeule}

As in other Bantu languages, the syntax of Ndendeule is richly encoded in the morphology. This section presents an overview of relevant features of the morphology and sentence construction.

The morphological structure of an Ndendeule verb is highly agglutinative, consisting of up to eight slots, as shown in (2). It consists of inflectional prefixes for relative marker, object marker, subject marker, tense, negation and object marker. The suffixes may be derivational, known as verb extensions, aspect marker and mood in the final slot.

(2) The morphological structure of an Ndendeule verb $\mathrm{RM} / \mathrm{COND}-\mathrm{SM}-\mathrm{NEG}-$ Tense $-\mathrm{OM}-$ Root - EXT - FIN

In any single verb, not all slots need be filled; the root is the only part that appears in all cases. Example (3) below illustrates the different parts of the verb with the root hemel 'buy'.

(3) bh-aki-ti-hemel-el-a ${ }^{3}$

2SM-PT-1PL-buy-APP-FV

'they bought for us'

In this example seven of the slots of the verb are filled. There is a subject marker agreeing with a Class 2 nominal (2SM), followed by prehodiernal past tense (PT). Immediately after tense, there is an object marker for 'us' (1PL). The root is followed by the derivational suffix -el, which is the applicative extension (APP). The final vowel (FV) marks the default indicative mood.

Ngonyani (2010) identifies five inflectional prefixes that express time, as shown in (4).

3 The orthography used in this paper follows Rugemalira, et al. (2012). 
(4)

$\begin{array}{ll} & \text { Tense } \\ \text { a. } & \text { Present } \\ \text { b. } & \text { Dependent } \\ \text { c. } & \text { Prehodiernal Past } \\ \text { d. } & \text { Indefinite Past } \\ \text { e. } & \text { Future }\end{array}$

Marker
-i-/ø
-aka-
-aki-
-a-
cha-

The prefix -i-/ø marks the present tense. For time before today (prehordiernal past), the prefix is $a k i$. The term "prehodiernal" is derived from Latin hodie 'today.' Therefore, prehodiernal past usually expresses events before today. In contrast to this, $-a$ - is not limited to hodiernal or prehordiernal past. It can be used with perfective aspect, for example, to refer to an event that happened earlier today or at a time before today. For this reason it is referred to as indefinite past. The 'dependent' marker - aka- serves several functions including 'go and X' and narrative; the sequential (narrative) reading appears in the following example.

(5) Bha-jend-a bh-aka-tol-e ma-toke
2SM-go-FV 2SM-DEP-take-SBJV 6-banana
'They should go and take bananas.'

The time reference for this tense is dependent on the first verb. Nurse \& Philippson (2006) call this tense the "subsecutive". However, this is only one sense of -aka-. These and other senses are well documented in Bantu languages. Historical and comparative evidence indicate that some of these may be homophones rather than one morpheme. ${ }^{4}$ One use of the affix in Ndendeule is to express a condition, as will be noted in the following section. With the exception of the future, tenses are marked by an affix that appears after the subject marker; the future marker appears before the subject marker.

Aspect is marked in the final slot of the full verb the same slot also occupied by the final vowel in non-perfective verbs. There are two aspect forms: perfective aspect and imperfective.

(6) Aspects and their markers

$\begin{array}{llll} & \text { Aspect } & \text { Marker } & \text { Meaning } \\ \text { a. } & \text { Perfective } & \text {-ite } & \text { Focus on termination of event } \\ \text { b. Imperfective } & \text {-á } & \text { Incomplete event }\end{array}$

The perfective aspect is marked by -ite but may be fused with the stem when the stem is longer than $\mathrm{CVC}$ in a process commonly known as imbrication. The imperfective is marked by a high tone on the final vowel, while reduplication marks events that are repeated. Ndendeule has a simple tone melody of LHL for verbs. This melody is assigned right to left. A high tone on the final syllable of the verb is either a result of some truncation or a marker of the imperfective. Tense and aspect is marked by segmental as well as suprasegmental features such as tone.

Tense and aspect interact in several ways, as shown in Table 1 summarizing the combinations.

4 I thank Steve Nicolle for pointing this out to me. 
Table 1: Tense and Aspect

\begin{tabular}{|l|l|}
\hline Label & Form \\
\hline Present & SM-i-OM-stem-a \\
\hline Prehodiernal Past & SM-aki-OM-stem-a \\
\hline Past Perfective & SM-a-OM-stem-ite \\
\hline Present Perfective & SM-i-OM-stem-ite \\
\hline Dependent Perfective & SM-aka-OM-stem-ite \\
\hline Past Imperfective & SM-a-OM-stem-á \\
\hline Present Imperfective & SM-i-OM-stem-á \\
\hline Dependent Imperfective & SM-aka-OM-stem-á \\
\hline Future Imperfective & cha-SM-OM-stem-á \\
\hline
\end{tabular}

Although tense and aspect are presented as distinct elements of the morphology, they often interact. In some cases tenses only appear but in others they appear together. Describing all these combinations is beyond the scope of this paper, but the role tense, aspect, and mood play in conditionals is significant. The combinations of tense in the conditional constructions are summarized in Table 2 below in $\S 3$.

One of the conditional markers involves negation. The main strategy for marking negation is the use of the particle $y i$ that appears after the predicate, as in the example below.

(7) a. n-geni aki-telek-a mbatata.

1-guest 1SM.PT-cook-FV 10potato

'The guest cooked potatoes.'

b. n-geni aki-telek-a yi mbatata

1-guest 1SM.PT-cook-FV NEG 10potato

'The guest did not cook potatoes.'

Sentence (7b) expresses negation of the affirmative (7a). The particle yi appears after the verb akiteleka 'she/he cooked.' This particle is also used for constituent negation in which case it appears after the negated constituent.

Mood is an important part of the morphology that contributes to the meanings of conditional constructions. Defined as a morphological expression of "modality" (Barbiers, 2002; Bosque, 2012; Palmer, 2001), mood expresses probability, certainty, necessity, volition, obligation, etc. Three moods are marked on the Ndendeule verb: (a) the indicative mood is marked by some form of tense, aspect and the final vowel $-a$; (b) the imperative mood is marked by the final vowel $-a$ and the obligatory absence of tense; and (c) the subjunctive mood is identified by its final vowel $-e$ and the obligatory presence of a subject marker, as shown in (8). 
(8)
a. bha-geni
bh-aki-bhuk-a
2-guest
2SM-PT-leave-FV
'The guests left.'

c. bha-bhuk-e

2SM-leave-SBJV

'They should leave.' b. bhuk-a!

leave-FV

'Leave!'

d. n-kotok-á ku-bhuk-a you-stop-IPFV INF-leave-FV

'Do not leave!'

The verb in (8a) carries the prehodiernal past marker -aki- after the subject marker, as well as the final vowel $-a$. In some cases the final vowel does not appear but is replaced by the perfect aspect marker as noted previously. Sentence (8b) in the imperative is made up of only the stem -bhuk'leave' and the final vowel. The subjunctive example (8c) bears the subject marker for class 2 $b h a-$, the root and the final subjunctive suffix -e. The negative form of the command is expressed by a periphrastic negative -kotoka 'stop' followed by the infinitive form of the main verb, as illustrated in (8d).

With respect to sentence structure, four features stand out as crucial in the description of conditionals in this language, as well as when comparing Ndendeule to other languages. First, basic constituent order is SVO. The second feature is a robust system of concord. The verb may carry a mark that agrees with a nominal with which it has syntactic relations in the subject position, object position, or the head of a relative clause. The third feature is that Ndendeule is a pro-drop language, whereby subject phrases are omitted but their agreement must appear as subject markers. The fourth feature is wh-in-situ. These features are exemplified in (9).

(9) a. bh-ana bh-aki-ghegh-a hanju.

2-child 2SM.PT-carry-FV 10.firewood

'The children carried firewood.'

b. bh-aki-ghegh-a niki?

2SM.PT-carry-FV what

'What did they carry?'

c. ghani aki-ghegh-a hanju?

who 1SM.PT-carry-FV 10.firewood

'Who carried firewood?'

d. aki-n-ghegh-el-a yi mbuya hanju.

1SM.PT-1OM-carry-APP-FVNEG 1grandma 10.firewood

'She/he did not carry firewood for grandma.'

Sentence (9a) exhibits the SVO structure. Notice also subject marking clearly marked in (9a) and (9b). The absence of subject phrases (pro drop) is illustrated in (9b) and (9d). The wh-word niki 'what' in (9b) is in the in-situ postverbal object position and the wh-word ghani 'who' in (9c) is in the in-situ preverbal subject position. These various aspects of the morphology and syntax contribute to the structure of conditional constructions by marking the protasis and apodosis, as well as in conveying meaning. 


\section{Marking Conditionals}

Conditionals are marked using a variety of devices. They include the subordinating conjunction, verbal inflectional and clause order. The different morphological markers and sentence structures are associated with different interpretations, as described later in $\S 5$. This section describes the constructions focusing on morphology and clause structure.

There are six conditional constructions. A summary of the conditional constructions is presented in Table 2. It shows the conditional marking device and the associated tense, aspect and mood elements. For the sake of convenience, we assign Roman numerals to each construction for easy reference.

Table 2: Marking conditionals

\begin{tabular}{|l|c|c|c|c|}
\hline & \multicolumn{2}{|c|}{ Protasis } & \multicolumn{2}{c|}{ Apodosis } \\
\hline & Protasis Marker & Protasis TAM & Apodosis Marker & Apodosis TAM \\
\hline I & anda & any tense or aspect & - (manya) & any tense or aspect \\
\hline II & nga- & IMPF & nga- & any tense or aspect \\
\hline III & -aka- & IMPF & - & any tense or aspect \\
\hline IV & nu- yi & INF & - (manya) & any tense or aspect \\
\hline V & - & SBJV, IMPV & - & SBJV \\
\hline VI & 2 clauses & SBJV & - & any tense or aspect \\
\hline
\end{tabular}

Construction I is marked by the only conditional subordinating conjunction anda 'if', which appears at the left edge of the protasis. Notice that the tense of the subordinate clause may be present, as in (10a), or past, as in the prehodiernal past in (10b). The apodosis is not marked in these examples.

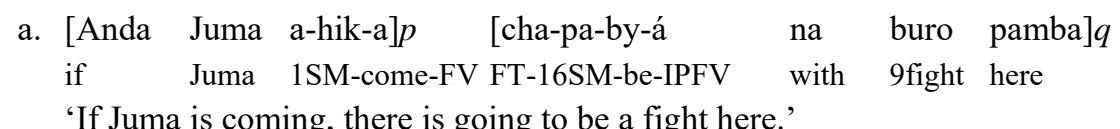
b. [Anda mayi aki-telek-a]p [bh-ana bh-aki-lyegh-a]q if 1.mother 1SM.PT-cook-FV 2-child 2SM-PT-eat-FV 'If the mother cooked, the children ate.'

The apodosis marker that is the equivalent of 'then' in English is manya. It is used optionally, especially for emphasis, as shown in (11a) and (11b).
(11) a. [Anda Juma a-hik-a]p [manya cha-pa-by-á na buro ]q if Juma 1SM-come-FV then FT-16SM-be-IPFV with 9fight 'If Juma is coming, there is going to be a fight.'

b. [Anda mayi aki-telek-a]p [manya bh-anabh-aki-lyegh-a] $q$ if 1.mother 1SM.PT-cook-FV then 2-child 2SM-PT-eat

'If the mother cooked, the children ate.' 
The conditional clause in (11a) is in present tense while the main clause is marked as future. In (11b), the protasis is in the past and the apodosis is in the past also. The protasis and apodosis verb can be past tense, present tense, perfect, future or habitual. Even infinitive verbs are available for such conditionals. We examine the interaction between the tenses and the conditional marker later in the paper.

Another set of conditional markers is expressed using inflections on the verb. One such inflection is nga- located before the subject prefix marking Construction II. This affix appears in both the main clause and the subordinate clause:

(12) a. [Nga-a-hik-á]p

[(manya) nga-ti-m-bwene.] $q$

COND-1SM-come-IPFV then COND-we-1OM-see.PF

'Had he/she come, we would have seen her/him.'

b. [Bh-ana nga-bha-gholw-ike] $q$ [nga-bha-pal-á]p

2-child COND-2SM-sleep-PF COND-2SM-want-IPFV

'The children would have slept had they wanted to.'

The verb in the if-clause must be imperfective, while the main clause verb may be marked with any tense. In (12a), the imperfective final high tone is on the verb of the first clause ngaahiká 'had she/he come,' while in (12b), it is marked on the verb of the second clause ngabhapala 'had they wanted.' The apodosis may in addition be marked with manya 'then', only when the apodosis follows the if-clause.

In $\S 2$, we identified -aka- as dependent expressing narrative or itive ('go and X)'. We also pointed out that it has been linked to a variety of senses and functions (Nurse and Philippson 2006). One of those functions is to introduce a protasis of Construction III. The apodosis in such constructions is not marked:
a. [aka-hik-á]p-n-telek-el-á] $q$
1SM.DEP-arrive-IPFV 2SG-1OM-cook-APP-IPFV
'When she/he arrives, cook for her/him.'
b. [m-aka-pal-á bhulo]p [n-kamul-e mbuhi y-angu. $] q$ 2SG-DEP-want-IPFV9 fight 2SG-catch-FV 9goat 9-my
'If you want a fight, catch my goat.'

Example (13a) shows an interaction between this marker and the imperfective in the main clause, while in (13b) the main clause is subjunctive. The dependent is a tense whose temporal reference is dependent upon another. In this case the temporal reference is linked to the imperative or the subjunctive in the main clause. The main clause can be marked for present, perfect, future, subjunctive and even imperative.

There is also a negative conditional clause marked by the prefix $n u$ - followed by the infinitive form of the verb and the negative particle $y i$. The conditional marker is a form of negative, which appears as na instead of $n u$ followed by the infinitive and the negative particle $y i$ (Ngonyani 2010). This is Construction IV and is shown in the following examples: 


\section{(14) a. [nu-ku-hik-a yi $] p \quad[$ b-andu ku-hyom-a $] q$ COND-INF-come-FV NEG 2-person INF-be angry-FV 'unless (he/she) comes, people will be angry' \\ b. [hula nu-ku-tony-a yi]p [li-mbaku cha-li-yum-a $] q$ 9.rain COND-INF-rain-FV NEG 5-tobacco FT-5OM-dry-FV 'if it does not rain, the tobacco plants will dry'}

The protasis expresses the negative condition. It is construed as if $\sim p, q$. The main clause in (14a) is infinitive, while in (14b) it is marked with a future marker. The main clause may also be present tense. In some contexts, such as narratives, the past tense is also used. The interpretation of the time referred to depends on the main clause.

Construction V appears as conjunction-less coordination. This is shown in the following example, where the if-clause is imperative or subjunctive and the main clause is subjunctive. The second example has a subjunctive form in the protasis too:

(15) a. [Kamul-a mbuhi y-angu]p [ni-m-put-e.]q catch-FV 9.goat 9-my 1SG-2SG-hit-SBJV

'Catch my goat and I will hit you.'

b. [a-yigh-e $] p \quad[$ a-lol-e $] q$ 1SM-try-SUBJ 1SM-see-SBJV

'She should try and she will see.'

The proper interpretation of (15a) is 'If you catch my goat, I will hit you.' Likewise, (15b) is understood as 'if she tries she will see.' This makes it similar to the English forms such as the following in (16a) and the logical representation in (16b).

(16) a. Kiss my dog and you'll get fleas.

p $q$

b. $p$ and $q \rightarrow$ if $p, q$

(Bhatt \& Pancheva, 2006:641)

c. Break that vase and I will break your neck.

(Fortuin \& Boogaart, 2009:642)

The two clauses are coordinated by a coordinating conjunction. The interpretation of (16a) is 'if you kiss my dog, you will get fleas.' In Ndendeule, the two clauses are not linked by an overt coordinating conjunction. However, the interpretation parallels that of the English construction. Unlike the English construction which has an imperative protasis, the Ndendeule protasis of this construction may be imperative (15a) or subjunctive (15b). Both moods express directives. The subjunctive enables the speaker to give directions even to a third person. These are the only two combinations for this implicit conjunction construction in Ndendeule.

Construction VI is described as the concessive conditional. This construction is unique in that 
the protasis is expressed by two opposing propositions. One way of expressing such an opposition is by the use of opposite verbs, such as, bhuka 'leave' and tama 'stay' (17a). Another way is negating the first proposition with the subjunctive periphrastic negative kotoka 'stop' (17b).

$\begin{array}{lllll}\text { (17) a. } & {[\text { A-bhuk-e }} & \text { a-tam-e }] p & \text { twe ti-telek-a } & \text { yi }] q \\ \text { 1SM-leave-SBJV } & \text { 1SM-stay-SBJV } & \text { we } & \text { 1PL.SM-cook-FV } & \text { NEG } \\ \text { 'Whether she/he leaves or stays, we will not cook.' } & \end{array}$

b. [A-bhuk-e a-kotok-e ku-bhuk-a]p 1SM-leave-SBJV 1SM-stop-SBJV INF-leave-FV

'Whether she/he leaves or doesn't leave,

[twe ti-telek-a yi]q
we 1PL-cook-FV NEG
we will not cook.'

The protasis consists of two clauses that express opposite propositions. The propositions may both be positive, as in (17a), or opposites, as in (17b). The effect of having two such opposites is the denial of the conditions. Therefore, conditions are expressed but the reality of the protasis is not contingent upon either of them.

To summarize, Ndendeule marks conditionals by (a) a subordinating conjunction anda 'if'; (b) verbal inflections, namely, nga-, dependent $-a k a-$ and negative conditional $n u-\ldots y i$; (c) conjunctionless directive conditionals; and (d) concessive conditionals marked by biclausal subjunctive protasis. For most of these constructions, variable clause order is available, as described in the following section.

\section{Clause Order}

Depending on how the conditionals are marked, there are fixed clause positions and some less fixed. In this section, we demonstrate that when the two clauses are marked differently, their order can vary without affecting the conditional construction.

Consider Construction I which is marked by anda 'if' in the protasis. The apodosis may be marked by manya 'then.' Either order of the clauses is possible:

(18) a. [Anda a-hik-a, $] p$ [cha-pa-bhy-á na bhuro pamba]q If 1SM-come-FV FT-16SM-be-IPFV with 9fight here

'If she/he is coming, there is going to be a fight here.'

b. [Cha-pa-bhy-á na bhuro pamba ]q [anda a-hik-a]p FT-16SM-be-IPFV with 9.fight here if 1SM-come-FV

'There is going to be a fight here if she/he comes.'

The order in (18a) is $p q$, while that in $(18 \mathrm{~b})$ is $q p$. Likewise, when the verb in the protasis is morphologically marked for conditional or other relevant affixes, either sequence of the clauses is acceptable. In the case of construction II, both clauses are marked with the verbal prefix nga-. 
However, the protasis can only be imperfective. The apodosis is marked with other tenses or aspects. In this way, the verb of the if-clause and the main clause are different.

(19)
a. [nga-a-hik-á ]p
[nga-ti-m-bwene.]q
COND-1SM-come-IPFV
COND-1PL-1OM-see.PF

'Had he/she come, we would have seen her/him.'
b. [nga-ti-m-bwene]q [nga-a-hik-á]p
COND-1PL-1OM-see.PF COND-1SM-come-IPFV

'We would have seen her/him had he come.'
(20) a. [mu-n-telek-el-a ]q [aka-hik-á ]q
2SG-1OM-cook-APP-FV 1SM.DEP-come-IPFV

'Cook for her/him when she comes.'

$\begin{array}{llll}\text { [n-kamul-á mbuhi y-angu] } & \text { [m-aka-pal-á } & \text { bhulo.]p } \\ \text { 2SG-catch-IPFV 9goat 9-my } & \text { 2SG-DEP-want-FV } & \text { 9fight } \\ \text { 'Catch my goat if you want a fight.' } & \end{array}$

In both pairs, $p q$ varies freely with $q p$, although there is a tendency to prefer the former. Conditional Construction V has a fixed order of $p q$ with the conditional clause the imperative or subjunctive and the main clause is subjunctive:
(21) a. [a-yigh-e]p [a-lol-e]q
1SM-try-SUBJ 1PL-see-SUBJ
'If she dares she will see.'
b. *[a-lol-e ]q [a-yigh-e]q
1SM-see-SUBJ 1SM-try-SUBJ
'If she dares she will see.'

The conditional reading that is provided in the translation is only possible with the $p q$ order that is found in (21a). The $q p$ order is not available, as example (21b) clearly demonstrates.

In short, the order of the two clauses is subject to marking of the conditional. The majority of conditionals involve differentiated marking either by a subordinating conjunction or by different morphological marking. This includes conditional nga-, dependent -aka-, and negative nu- ... yi. The only fixed order conditional involves morphological marking that does not differentiate the two clauses. In the fixed order conditional, the protasis appears before the apodosis. Regardless of how the conditional is marked, there are no conditional constructions in which the order of the two clauses is only $q p$. Therefore, in Ndendeule, the interpretation of the conditionals depends mainly on conditional marking and, to a far lesser extent, on TAM, as described in the following section. 


\section{Interpretation of Conditionals}

It is widely understood that in many languages, the interpretation of conditional constructions results from the interaction of tense, aspect and mood, as well as the markers of protasis and apodosis (Comrie 1986; Podlesskaya 2001; Thompson et. al. 2007; Tynan \& Lavin 1997; Schachter 1971; Saloné 1983; Taylor 1997). In this section, we examine the interpretation of conditionals in Ndendeule and explore the contribution of the tenses, mood and conditional markers.

One of the most widely referenced classifications of conditionals was proposed by Schachter (1971). She classifies conditionals into reality conditionals and unreality conditionals. Reality conditionals express propositions that have or had a possibility of being realized. For example:

(22) a. If you step on the brake, the car slows down.

b. If the North Vietnamese agreed, the South Vietnamese disagreed.

c. If it's raining out there, my car is getting wet.

(Schachter 1971:70)

The condition in (22a) obtains always, while in (22b) expresses a condition that existed. In (22c), the speaker makes a prediction. Unreality conditionals express: (a) imaginary or hypothetical situations, (b) counterfactual or impossible situations and (c) future time conditionals in (23).

(23) a. If I saw a winged horse, I'd faint. (hypothetical)

b. If I were you, I wouldn't talk like that. (counterfactual)

c. If mother comes, I'll be able to collapse. (future conditional) (Schachter 1971:65)

Schachter refers to (23a) and (23b) as imaginative conditionals expressing either an imaginary situation that is not strongly negated (23a) or an impossible situation that cannot happen (23b). Schachter's classification is partially guided by tense and aspect because the combinations of tense and aspect give rise to different interpretations of the conditions with respect to reality or unreality. For example, in English, the combination of the past perfect had and the verb in the protasis and would have and the verb in the apodosis leads to an interpretation of unreality (24a). A simple past in the if-clause and the modal would in the main clause give rise to unreality in (24).

(24) a. If 50 pages had been enough, I would have finished long ago. (Schachter 1971:63)

b. If Nixon collapsed, chaos would ensue. (Schachter 1971:64)

The combination of had been in the if-clause in (24a) and the past time in the main clause expresses a counterfactual meaning. In (24b), the simple past in the if-clause and the modal would in the main clause, which does not clearly demarcate time, produce a hypothetical reading.

In Ndendeule, tense does not determine the reality or unreality of the conditionals, a fact also noted in Swahili (Saloné 1983). This can be demonstrated with protasis clauses in different tenses and aspects. The subordinating conjunction anda 'if', for example, appears with verbs in the past 
tense, present tense, future tense and perfect aspect. This is demonstrated in the following examples.

(25) a. [Anda aki-ghegh-a machi,]p [bh-ana cha-bha-yogh-á.]q If 1SM.PT-carry-FV 6.water 2-child FT-2SM-bathe-IPFV

'If she/he carried water, then the children will bathe.'

b. [Anda i-ghegh-a machi,]p [bh-ana cha-bha-yogh-á.] $q$

If 1SM.PR-carry-FV 6.water 2-child FT-2SM-bathe-IPFV

'If she/he is carrying water, then the children will bathe.'

c. [Anda cha-a-ghegh-ámachi,]p [bh-ana cha-bha-yogh-á]q.

If FT-SM-carry-IPFV 6.water 2-child FT-2SM-bathe-IPFV

'If she/he will carry water, then the children will bathe.'

d. [Anda a-ghegh-ite machi,]p [bh-ana cha-bha-yogh-á.]q

If $\quad$ 1SM -carry-PF 6.water 2-child FT-2SM-bathe-IPFV

'If she/he carried water, then the children will bathe.'

In all four sentences, the protasis is marked by the subordinating conjunction anda 'if.' In (25a), the protasis is in the past tense, while in $(25 b)$ it is present. The verb in the if-clause of $(25 c)$ is future, while that in (25d) bears a perfect aspect marker. The matrix clauses are all future. All of the conditional sentences are interpreted as possible situations regardless of the tense in which they are marked. Varying the tenses of the apodosis also does not affect the reality of the conditional construction. The sentences in (26) all have conditional clauses marked by anda 'if' and past tense. The main clauses are in future, present, past and perfect.

(26) a. [Anda aki-ghegh-a machi,]p [bh-ana cha-bha-yogh-á.]q If 1SM.PT-carry-FV 6.water 2-child FT-2SM-bathe-IPFV

'If she/he carried water, then the children will bathe.'

b. [Anda aki-ghegh-a machi,]p [bh-ana bh-i-yogh-a.]q If 1SM.PT-carry-FV 6.water 2-child 2SM-PR-bathe-FV

'If she/he carried water, then the children are bathing.'

c. [Anda aki-ghegh-a machi,]p [bh-ana bh-aki-yogh-a.]q If 1SM.PT-carry-FV 6.water 2-child 2SM-PT-bathe-FV 'If she/he carried water, then the children bathed.'

d. [Anda aki-ghegh-a machi, $] p$ [bh-ana bha-yogh-ite.] $q$ If 1SM.PT-carry-FV 6.water 2-child 2SM-bathe-PF 'If she/he carried water, then the children bathed.'

Unlike the sentences in (25), these sentences have the same protasis. The apodoses are future (26a), present (26b), past tense (26c) and perfect (26d). Variations of the tense and aspect of the 
apodosis has not affected the reality of the protasis. All conditions are interpreted as possible. The tense in the matrix clause of the if-clause signals the various temporal points of the events. This is true of all conditional constructions.

Conditional marking, however, bears many of the senses of the reality or unreality of the conditional construction. Tynan and Lavin (1997) note that the choice of the conditional marker is an explicit signal of the speaker's assumptions about the truth of the protasis or antecedent. In Ndendeule, there are four distinctive conditional markers labeled I - IV in Table 3 with their "interpretations".

Table 3: Interpretations associated with protasis markers

\begin{tabular}{|l|l|l|}
\hline & Protasis Marker & Interpretation \\
\hline I & anda & Probable \\
\hline II & nga- & Counterfactual \\
\hline III & -aka- & Temporal, factual \\
\hline IV & nu+INF & Probable negative \\
\hline
\end{tabular}

Of all the conditional markers in Ndendeule, -nga- is the one that clearly expresses imaginary situations. Moreover, it makes no distinction between Schachter's hypothetical and counterfactual conditionals. Sentences similar to the two English conditional sentences in (27) demonstrate this:

a. [Nga-ni-yi-bhon-a mbuhi yi-na ma-papanilu,]p

COND-I-9OM-see-FV 9.goat 9SM-with 6-wing

'If I saw a winged goat,

[nga-hindw-ike] $q$

COND-faint-PF

I would faint.'

b. [Nga-m-y-a mwe,]p [nga-nong-ile yi naha.] $q$ COND-I-be-FV youCOND-I.talk-PF NEG this way

'If I were you, I wouldn't talk like that.'

The conditional prefix is a clear signal that the speaker assumes the proposition stated in the protasis to be non-factual. In (27a) a winged goat exists only in the imaginary world. Likewise, in (27b), I am not you. Therefore, this is not something in the real world.

Propositions known to be non-factual are not expressed by other conditional markers. Consider the following, which are semantically anomalous: 
(28) a. *[Anda ni-yi-bhon-a mbuhi yi-na

if $1 \mathrm{SG}-9 \mathrm{OM}-\mathrm{see}-\mathrm{FV}$ 9.goat 9SM-with

'If I see a winged goat,

ma-papanilu, ]p [ni-hinduk-a] $q$

6-wing 1SG-faint-FV

I faint.'

b. *[Anda mi mwe, $] p$ [nongel-a yi naha.] if 1SG-be you 1SG.talk-PF NEG this way

'If I were you, I wouldn't talk like that.'

The conditional particle anda 'if' cannot be used with such propositions, precisely because it bears the assumption of a possible world. In fact, even when nga- is used to express propositions that are possible in this world, the resulting reading is that it did not happen:

(29)
a. [Nga-a-hik-á]p
[nga-ti-m-bwene]q

COND-1SM-arrive-FV COND-we-1OM-see

'Had she/he come, we would have seen him/her.'
b. [Nga-ti-pal-á ku-bhuk-a]p [nga-ti-bhuk-ite]q COND-we-want-FV INF-leave-FV COND-we-leave-PF
'Had we wanted to leave, we would have left.'

In (29a), she/he could have come, but the use of nga-indicates that this did not happen. Likewise, in (29b), the speaker expresses that the antecedent did not happen. In addition, the resulting reading is that we did not leave because we did not want to. For this reason, we consider nga- as simply expressing a counterfactual condition.

The other three conditional markers all express reality on a cline. At one end is the temporal conditional marker -aka-, which expresses a presumption that the proposition of the protasis is factual. The other point is where anda 'if' and the negative conditional $n u+$ INF are used to express an open possibility of the event in the protasis. The speaker does not commit to the truth of the if-clause, but it is open to the possibility, all exemplified in (30). The conditional clauses, such as in (30a) marked by anda and in (30b) marked by nu + INF and the negative particle, are probable. The -aka- in (30c) suggests that the speaker assumes that whomever he or she is talking about will leave; it is only a matter of time.

(30) a. [Anda bh-aki-telek-a]p [manya hukulu a-l-ile]q if 2SM-PT-cook-FV then 1.grandpa $1 \mathrm{SM}$-eat-PF

'If they cooked, then grandpa must have eaten.'

b. [Nu-ku-telek-a $\quad$ yi]p $\quad$ [bh-ana ku-gholok-a na njala $] q$ COND-INF-cook-FV NEG 2-child INF-sleep-FV with 9.hunger

'Without (someone) cooking, the children will sleep without eating.' 
c. [Bh-aka-bhuk-á]p [ti-longel-á]q

2SM-DEP-leave-FV we-talk-FV

'Once they leave, we can talk.'

Only the conditional clause with the dependent -aka- expresses certainty regarding the event in the protasis.

It appears that the conditional markers reflect what Taylor (1997) describes as a gradient of epistemic likelihood of the if-clause. At one end of the gradient, there are factual conditionals, and at the other, there are counterfactuals. Taylor provides the following examples in (31) for his gradient.

(31) a. If he said that (and we heard him say it!) he's a liar.

(Factual: $p$ is presumed to be the case)

b. If he said that, he'd be a liar.

(Hypothetical: $p$ is probable)

c. If he had said that (which he didn't), he would be a liar.

(Counterfactual: $p$ is presumed not to be the case)

(Taylor 1997:302)

We notice how the context distinguishes the conditional meaning in (31a) and (31b) which, otherwise, have the same protasis. The different interpretations are partly due to the tense and modality expressed in the apodosis in English. The present tense apodosis results in the factual reading. The probable reading is evidently a result of the past tense. This is not the case for Ndendeule.

We have already provided examples demonstrating how varying tense and aspect does not contribute to the conditional interpretation in Ndendeule. We now consider mood. The three moods all appear in different conditional constructions. The default mood is indicative. Two other moods, imperative and subjunctive, appear with specific pragmatic functions of directing or instructing. All the matrix clauses have a directive function marked by the imperative mood, as shown in (32).

(32) a. [Anda bh-i-hik-a]p [ma-bha-telek-el-a]q if 2SM-PR-arrive-FV 2PL-2OM-cook-APP-FV

'If they come, cook for them.'

b. [Bh-aka-hik-á]p [ma-bha-telek-el-a]q 2SM-DEP-arrive-FV 2PL-2OM-cook-APP-FV

'When they come, cook for them.'

c. $[\mathrm{Nu}-\mathrm{ku}-\mathrm{yomol}-\mathrm{a} \quad \mathrm{yi}] p \quad[\mathrm{n}$-golok-a papa $] q$

COND-INF-finish-FV NEG 2PL-sleep-FV there

'If you don't finish, you sleep right there.' 
In (32a), the if-clause expresses a possible condition and the main clause directing the addressees to 'cook for them.' The condition in (32b) is marked by the dependent and imperfective, while the main clause uses the imperative, as in the previous example. The negative condition in (32c) is followed by an imperative in the main clause.

The directive function is also possible with the subjunctive also in the matrix clauses, as in (33).

a. $\begin{array}{lll}\text { Anda } & \text { bh-i-hik-a }] p & \text { [ma-bha-telek-el-e }] q \\ \text { if } & 2 \mathrm{SM}-\mathrm{PR} \text {-arrive-FV } & \text { you-2OM-cook-APP-SUBJ } \\ \text { 'If they come, cook for them.' }\end{array}$

b. [Bh-aka-hik-á $] p \quad[$ ma-bha-telek-el-e] $q$ 2SM-DEP-arrive-FV you-2OM-cook-APP-SUBJ

'When they come, cook for them.'
c. $[$ Nu-ku-yomol-a yi]p [n-golok-e papa $] q$ COND-INF-finish-FV NEG you-sleep-SUBJ there 'If you don't finish, you should sleep right there.'

In place of the imperative inflection in the main clause, there is the subjunctive. As in the imperative, the apodosis here directs some action, albeit in a more polite and less manipulative manner. The directive function is clear as the imperative and subjunctive are both marked in the matrix clause. The reality or unreality is established by the conditional marker in the protasis. The pragmatic function, in this case the illocutionary force of directing or suggesting, is expressed by the mood in the matrix clause.

To summarize, the conditional interpretation in Ndendeule depends largely on the marking of the protasis. TAM does not contribute to determining reality or unreality but to locating the event in time and in expressing an illocutionary function.

\section{Conclusion}

This article aimed to describe conditional constructions in Ndendeule. Based on marking the conditional, six constructions were identified. Four are: (a) the conditional particle anda 'if'; (b) verbal prefix nga-, which appears before the subject marker; (c) verbal prefix $-k a-$, which appears in the tense slot; and (d) prefix nu-, which appears on an infinitival verb followed by the negative particle yi. Two conditional constructions are not uniquely marked. One uses an implicit coordination between the imperative and subjunctive clauses. The other is a concessive conditional that is characterized by the antecedent consisting of two opposing subjunctive clauses. The order of the clauses is critical only in the coordinate construction in which the protasis must appear before the apodosis.

Semantically, the four conditionals that are marked with a subordinating conjunction or an inflection fall into Taylor's (1997) gradient. At the one end of the gradient are factual conditionals marked by -aka-, and at the other, counterfactual conditionals marked by nga- on both the protasis and apodosis. In between the two are conditionals for which the speaker is non-committal with respect to whether it is a fact or not. 
The description that is presented in this paper calls for further investigation in order to gain a more detailed picture of conditionals. For example, while the description focused on the meanings of the if-clauses, much needs to be said about the functions of the apodosis and the interpretations that arise. There is also a need to determine the position of the adverbial clause in the sentence structure. The origin of the conditional markers may be investigated to find clues about how they result in different interpretations of the conditionals.

\section{Abbreviations used}

$\begin{array}{llll}\text { APP } & \text { applicative } & \text { NEG } & \text { negative } \\ \text { COND } & \text { conditional } & \text { DEP } & \text { dependent } \\ \text { EXT } & \text { extensions } & \text { PF } & \text { perfective aspect } \\ \text { FIN } & \text { final elements } & \text { OM } & \text { object marker } \\ \text { FT } & \text { future tense } & \text { RM } & \text { relative marker } \\ \text { FV } & \text { final vowel } & \text { PT } & \text { prehodiernal past tense } \\ \text { HAB } & \text { habitual } & \text { SM } & \text { subject marker } \\ \text { INF } & \text { Infinitive } & \text { SBJV } & \text { subjunctive }\end{array}$

\section{References}

Barbiers, Sjef. 2002. Current issues in modality: an introduction to modality and its interaction with the verbal system. In S. Barbiers, F. Beukema, \& W. van der Wurff (eds.), Modality and its Interac Tanzania. Sprache und Geschichte in Afrika, 9, 15-115.

Bhatt, Rajesh \& Pancheva, Roumyana. 2006. Conditionals. In M. Everaert, \& Henk van Riemsdijk (eds.), The Blackwell Companion to Syntax, Vol. 1, 637-687. Oxford: Blackwell.

Bosque, Ignacio. 2012. Mood: indicative vs. subjunctive. In José I. Hualde, Antxon Olarrea, \& Erin O'Rourke (eds.), The Handbook of Hispanic Linguistics, 373 -394. Blackwell.

Comrie, Bernard. 1986. Conditionals: a typology. In Elizabeth C. Traugott, Alice ter Meulen, Judy S. Reilly, \& Charles A. Ferguson (eds.), On Conditionals, 77-99. Cambridge: Cambridge University Press.

Fortuin, Egbert Boogaart, Ronny. 2009. Imperative as conditional: from constructional to compositional semantics. Cognitive Linguistics 20, 1:641-673.

Guthrie, Malcolm. 1967-71. Comparative Bantu (Vols. I - IV). Farnborough: Gregg Press.

Maho, Jouni. 2003. A classification of the Bantu languages: an update of Guthrie's referential system. In Derek Nurse \& Gerard Philippson (eds.), The Bantu Languages, 639-651. London: Routledge.

Mradi wa Lugha za Tanzania. 2009. Atlasi ya Lugha za Tanzania. Dar es Salaam: Chuo Kikuu cha Dar es Salaam.

Ngonyani, Deo. 2010. A Grammar of Kindendeule (ms). East Lansing, MI: Michigan State University.

Nurse, Derek. 1988. The diachronic background to the language communities of southwestern. 
Nurse, Derek \& Philippson, Gérard. 2006. Common tense-aspect markers in Bantu. Journal of African Languages and Linguistics, 27:155-196.

Palmer, Frank R. 2001. Mood and Modality. Cambridge: Cambridge University Press.

Podlesskaya, Vera 2001. Conditional constructions. In Martin Haspelmath (ed.), Language

Typology and Language Universals: An International Handbook, Vol. 2, 998-1010.

Berlin/New York: Walter De Gruyter.

Quirk, Randolph, Sidney Greenbaum, Geoffrey Leech, \& Jan Svartvik. (1985). A Comprehensive Grammar of the English Language. London: Longman.

Rugemalira, Josephat, Muzale, Henry, Ezekiel, P., Kindija, Kulwa, Mrikaria, George, Lema, B. P., et al. 2012. Harmonization of the Orthography of Bantu Languages of Tanzania. Cape Town: Center for Advanced Study of African Society.

Saloné, Sukari B. 1983. Conditional Sentences in Swahili. University of California, Los Angeles: Doctoral Dissertation.

Schachter, Jacqueline C. 1971. Presupposition and Counterfactual Conditional Sentences. University of California, Los Angeles: Doctoral dissertation.

Thompson, Sandra. A., Longacre, Ronald. E., \& Hwang, Shin Ja 2007. Adverbial Clauses. In Timothy Shopen (ed.), Language Typology and Syntactic Description; Volume II Complex Constructions, 237-300. Cambridge: Cambridge University Press.

Taylor, John R. 1997. Conditionals and polarity. In Angeliki Athanasiadou, \& René Dirven (eds.), On Conditionals Again, 289-306. Amsterdam/Philadelphia: John Benjamins.

Tynan, John \& Lavin, Eva D. 1997. Mood, tense and the interpretation of conditionals. In Angeliki Athanasiadou, \& René Dirven (eds.), On Conditionals Again, 115-142. Amsterdam/Philadelphia: John Benjamins.tion with the Verbal System, 1-17. Philadelphia: John Benjamins.

\footnotetext{
Deo Ngonyani dngonyani@gmail.com
}

Submitted: 16 September 2015 Accepted: 16 March 2016

Revisions: 14 June 2016 